\title{
sdmimd
}

\section{Impact of Dividends on Share Price Performance of Companies in Indian Context}

Kavita Chavali and Nusratunnisa

School of Business - Alliance University, Bangalore

\begin{abstract}
The study aims at finding the impact of dividends (cash and stock) on share price performance of companies in the Indian context. A sample of 67 fast moving consumer goods companies who made dividend announcements from April 2007 to August 2011 are taken. In this study, the Market Model Event Study Methodology has been employed to measure the effect of dividend announcements and its impact on the share price with a 41-day event window is taken. The stock price data is collected for 20 days prior to the dividend announcement, the share price on the announcement date (An date) $\mathrm{t}_{0}$ and 20 days post the dividend announcement. The findings indicate that the market is found to react positively to dividend announcements and with a significantly positive Average Abnormal Returns (AAR) around the announcement date.
\end{abstract}

Keywords: dividends, investor's reaction, event study, abnormal returns

\section{Introduction}

Dividend decisions have myriad and long-standing strategic implications on a company in the form of adding or depleting value created to the shareholder. There are two schools of thought of dividend policy, i.e. Dividend Relevance and Dividend Irrelevance. One stream of thought believes that dividends are an important determinant of firm value (Gordon, 1959; Lintner, 1956). The other perspective is that dividends are irrelevant for firm value, and on the contrary, is possibly value-destroying (Black, 1976). Miller and Modigliani (1961) propose that in a world of no taxes and transaction costs, dividends are irrelevant to investors. They argue that the value of the company and its share price are unaffected by the distribution of dividends. The value of the company is determined solely by the earning power and its assets but not by the manner it splits its earning stream, i.e., retention and payout ratio.

Corporate event announcements are important to the shareholder as they lend valuable information regarding the corporate events in which dividend announcement is one, which the company undertakes that impacts their investment choice. In fact, information about corporate event announcements and stock market efficiency are of greater interest not only to the investors but also to financial analysts, planners, mutual fund managers, policy makers and market regulators, researchers, the government and the public in general. The present study is aimed at finding the impact of dividend announcement on the share price performance using event study methodology in the Indian context.

\section{Literature Review}

A lot of theoretical and empirical research has been done in the past on the impact of dividends on shareholders and the relationship between stock prices and dividends, which has shown mixed results. One of the earliest studies was done by Pettit (1972) who found that the market made use of dividend change announcements in pricing securities. The study conducted in the United States of 
America on a sample size of sixty seven firms paying dividend, found that market participants make use of information in pricing securities.

\subsection{Dividend Decision, Information Asymmetry and Signaling Hypothesis}

Signaling in various ways as a forbearer of the future health of an organization is a dynamic study. The present study investigates whether signaling hypothesis holds true in case of dividend announcements. The concept of signaling pioneered by Ackerloff (1970) and Spence (1973) attempts to explain dividend policy and earnings of the company in the future. One of the assumptions of signaling hypothesis is that dividend changes are positively correlated with share price and future earnings. Bhattacharya (1979) proved that there exists asymmetric information between a firm's management and its shareholders. Hence any increase or decrease in dividends conveys price-sensitive information to shareholders and prospective investors. Balachandran and Balasingham (1998) concluded that interim dividends conveyed more information than final dividends. Miller and Rock (1985) and John and Williams (1985) also support the signaling hypothesis proposition. Test of significance of dividend changes showed that the capital market reacts favorably to news announcements like dividend payouts which are perceived to be good (Michaely, Thaler \& Woack, 1995).

\subsection{Dividend Decision and Agency Conflict}

Dividends speak about the actions of the managers and help the investors monitor the behavior of managers through dividend decisions. Easterbrook (1984) proposed that dividends play a role in decreasing or increasing agency conflict between management and shareholders. When a firm's management increases dividends to shareholders, it pays out any excess cash resulting in positive changes in stock prices and vice versa.

\subsection{Dividends and Semi-strong form of Market Hypothesis}

The semi-strong form suggests that stock prices rapidly adjust to any unexpected material (in this context, unexpected increase or decrease in dividends) informa- tion. Through event study, it is measured how rapidly security prices respond to dividend announcements. The studies conducted on stock price reaction are based on the test of semi-strong form of market efficiency. Akbar and Baig (2010) have done a study in Karachi Stock Exchange to test semi-strong form of market efficiency by investigating the reaction of stock prices to dividend announcements of seventy nine companies. The Average Abnormal Return for cash and stock dividends is mostly positive. Sharma (2011) has obtained results of daily series of Average Abnormal Return and Cumulative Average Abnormal Return indicating that the investment strategies based on dividend announcement events cannot result in significant abnormal returns for the investors. The sector-specific analysis has not indicated any signals of inefficiency, which further strengthened the argument in favor of Semi-Strong Form Efficiency in Indian stock markets. It indicated that the slightest possibility of leakage of accounting information may not turn into abnormal profit for the investors.

\subsection{Dividend Announcements, Market Reaction and Stock Returns}

Lintner (1956) in his research suggests that a firm's management will resort to increasing dividends if it believes that the increase will be permanent. The average stock price drops on the ex-dividend date. The drop is around 90 per cent when the stock market is stable (Campbell and Beranek, 1955). Ball and Kothari (1991), investigated quarterly earning's announcements and stock prices in the US from 1980 to 1988 , finds that abnormal returns persisted after earning announcements. Gordon (1962), Foster and Vickery (1978) document evidence that suggest positive abnormal returns to dividend payment announcements whereas Easton and Sinclair (1989) find negative abnormal returns, i.e., a negative reaction by stock prices to dividend announcements; which is attributed to the tax effect of dividends for shareholders. Lonie, et al. (1996) investigates the dividend announcements of $620 \mathrm{UK}$ companies from January to June 1991 using event study and interaction tests. They find that investors responded to the increase or decrease in dividends. However, their findings also reveal that, even for companies with no change in dividends, the average abnormal returns one day prior to the announcements were significantly different from zero as indicated by the $t$ statistic. 


\section{Methodology}

The data pertaining to dividend announcements is taken from Capitaline database. A sample of 67 fast moving consumer goods (FMCG) companies which made a dividend announcement during the period April 2007 to August 2011 has been considered in the study. The impact of the global financial crisis on the price performance of the sample companies is not considered, which can be a limitation to the study. The approved meeting date is taken as the announcement date (An date). The stock price data is collected from a total of 41 trading days, 20 days prior to the dividend announcement, the share price on the announcement date $(\underline{\text { An date }}) \mathrm{t}_{0}$ and also share prices of 20 trading days post An date. In this study, the Market model event study methodology has been employed to measure the impact of dividend announcements and its impact on the share price. The Market model has been chosen because it is powerful in detecting abnormal returns when compared to other elaborate methodologies like Index model, which is free from criticisms of the Capital Asset Pricing Model. Brown and Warner (1985) have specified that market model is well specified based on simple methodology and relatively powerful under a wide variety of conditions. The study determines the abnormal returns associated with the dividends around the announcement dates and the speed with which the information relating a dividend decision made by the company is absorbed into the share prices in the market. This is done using the Market Model Event Study Methodology. The Abnormal Returns, Average Abnormal Returns (AAR) and Cumulative Average Abnormal Returns (CAAR) have been derived using the following equations:

Calculation of Abnormal Returns to gauge the impact on the market price of the stock due to dividend announcement is done by using the formula:

- Daily Abnormal Return : $\mathrm{AR}_{\mathrm{it}}=\mathrm{R}_{\mathrm{it}}-\mathrm{ER}_{\mathrm{it}}$

Where, $\mathrm{R}_{\mathrm{it}}$ is the daily return on security $\mathrm{i}$ on day $\mathrm{t}, \mathrm{ER}_{\mathrm{it}}$ is the expected daily return on security $i$ on day $t$.

Abnormal returns are computed for all the 67 sample companies/stocks for the 41-day event window.
The Daily Returns on Stock/security i for the respective companies in the sample have been calculated using the formula:

- Daily Return on stock : $\mathrm{R}_{\mathrm{it}}=\left(\right.$ Close price on ${ }_{\mathrm{t}-1}-$ Close price on $\mathrm{t}$ )/ Close price on ${ }_{\mathrm{t}-1}$

Where, $t$ is the time or day for which the daily return on stock is calculated.

The BSE price index is used for computing market return. The daily market return has been calculated by the formula:

- Daily Market Index Return : $\mathrm{R}_{\mathrm{mt}}=$ (Close price on $_{\mathrm{t}-1}$ - Close price on $t$ )/ Close price on $t-1$

Where, $\mathrm{R}_{\mathrm{mt}}$ is the daily return on market index, $\mathrm{t}$ is the time or day for which the daily return on BSE market index.

The expected returns $\left(\mathrm{ER}_{\mathrm{it}}\right)$ for security $\mathrm{i}$ at day $\mathrm{t}$ are defined as,

- Expected Returns on security/stock : $\mathrm{ER}_{\mathrm{it}}=\alpha \mathrm{i}+\beta \mathrm{i} \cdot \mathrm{R}_{\mathrm{mt}}$

Where, $\alpha \mathrm{i}, \beta \mathrm{i}$ are the regression coefficients of security i which are derived from Market Model developed for each of the respective stocks.

The Abnormal Return computation is based on the formula:

- Daily Abnormal Return : $\mathrm{AR}_{\mathrm{it}}=\mathrm{R}_{\mathrm{it}}-\mathrm{ER}_{\mathrm{it}}$.

Where, $\mathrm{R}_{\mathrm{it}}$ is the Daily Return on stock/security i, ERit is the Expected Returns on stock/security $i$.

- The Average Abnormal Returns for all companies are defined as:

$$
\operatorname{AAR}_{\mathrm{t}}=\underset{\mathrm{i}=1}{\mathrm{n}} \ln _{\mathrm{n}} . \sum \mathrm{AR}_{\mathrm{it}}
$$

Where, $\mathrm{t}=-20$ to +20 and $\mathrm{n}$ is the sample size.

To analyze the impact of dividends on stock price performance, the Cumulative Abnormal Returns (CAR) 
and Cumulative Average Abnormal Returns (CAAR) have also been calculated for the 41 days centered in the announcement dates.

- CAAR (Cumulative Average Abnormal Returns) for event time period say $t_{1}$ to $t_{2}$ are computed as follows: $\mathrm{t}_{2}$

$$
\underset{\mathrm{CAAR}}{=}=\mathrm{t}_{1} \mathrm{AAR}_{\mathrm{it}}
$$

Where, $\mathrm{t}=\mathrm{t}_{1}$ to $\mathrm{t}_{2}$.

$$
\mathrm{AAR}_{\mathrm{it}}=\text { Average Abnormal Returns }
$$

The hypothesis was formulated based on the studies done in the past.

The study is based on the following hypothesis:

1. Null Hypothesis (Ho): There is no significant impact of dividend announcement on the average abnormal return.

2. Alternative Hypothesis (Ha): There is a significant positive impact of dividend announcement on the average abnormal return.

For testing the hypothesis, t-test is computed for hypothesis testing, to reject or fail to reject the null hypothesis.

\section{Findings}

The study is to find out whether there is an impact of dividend announcement using Market Model methodology by taking the event study of 20-day pre- and 20-day post-dividend announcements. The Alpha and Beta, i.e., regression coefficients of the sample stock selected and $t$ statistic for each company is calculated. The Average Abnormal Return, Cumulative Abnormal Return and the Cumulative Average Abnormal Return are calculated.

Table 1 presents results for each of the 41 days (period of 20 days prior and 20 days post) dividend announcement in the sample period for 67 companies along with the test statistics for testing the null hypothesis. The table indicates that there is no consistent pattern of the Average Abnormal Returns
(AARs). Null Hypothesis is rejected on $\left(t_{-14}\right)\left(t_{-6}\right)\left(t_{2}\right)\left(t_{6}\right)$ $\left(t_{10}\right)\left(t_{11}\right)\left(t_{13}\right)$ and $\left(t_{14}\right)$. It signifies that the AAR is positive on these days and is significant also. The Cumulative Average Abnormal Return is positive in the pre-and post-announcement scenario. In the study conducted, it is observed that stocks experienced positive Average Abnormal Return on the An date $\left(\mathrm{t}_{0}\right)$, a strong evidence in support of a semistrong efficient market hypothesis, particularly near $\left(\mathrm{t}_{1}\right)\left(\mathrm{t}_{2}\right)$ $\left(\mathrm{t}_{3}\right)\left(\mathrm{t}_{5}\right)\left(\mathrm{t}_{6}\right)\left(\mathrm{t}_{7}\right)\left(\mathrm{t}_{12}\right)\left(\mathrm{t}_{14}\right)\left(\mathrm{t}_{15}\right)\left(\mathrm{t}_{16}\right)\left(\mathrm{t}_{17}\right)\left(\mathrm{t}_{19}\right)\left(\mathrm{t}_{-3}\right)\left(\mathrm{t}_{-5}\right)\left(\mathrm{t}_{-7}\right)\left(\mathrm{t}_{-8}\right)$ $\left(\mathrm{t}_{-9}\right)\left(\mathrm{t}_{-14}\right)\left(\mathrm{t}_{-15}\right)\left(\mathrm{t}_{-18}\right)\left(\mathrm{t}_{-19}\right)\left(\mathrm{t}_{-20}\right)$ to the An date. On the, An date

\begin{tabular}{|c|c|c|c|c|c|c|}
\hline Day & $\mathbf{N}$ & AAR $\%$ & T Statistic & $\begin{array}{l}\text { Null Hypothesis } \\
\text { Test }\end{array}$ & CAR $\%$ & CAAR $\%$ \\
\hline$\overline{-20}$ & 67 & 7.23 & 1.345 & Fail to Reject Ho & 0.11 & 0.11 \\
\hline-19 & 67 & 8.62 & 0.359 & Fail to Reject Ho & 0.13 & 0.24 \\
\hline-18 & 67 & 19.74 & 0.695 & Fail to Reject Ho & 0.29 & 0.53 \\
\hline-17 & 67 & -17.53 & -0.633 & Fail to Reject Ho & -0.26 & 0.27 \\
\hline-16 & 67 & -4.41 & -0.156 & Fail to Reject Ho & -0.07 & 0.20 \\
\hline-15 & 67 & 34.51 & 1.442 & Fail to Reject $\mathrm{Ho}$ & 0.52 & 0.72 \\
\hline-14 & 67 & 53.58 & 1.899 & Reject Ho & 0.80 & 1.52 \\
\hline-13 & 67 & -19.26 & -0.738 & Fail to Reject Ho & -0.29 & 1.23 \\
\hline-12 & 67 & -11.77 & -0.403 & Fail to Reject Ho & -0.18 & 1.05 \\
\hline-11 & 67 & -7.73 & -0.307 & Fail to Reject Ho & -0.12 & 0.93 \\
\hline-10 & 67 & -28.85 & -0.994 & Fail to Reject Ho & -0.43 & 0.50 \\
\hline-9 & 67 & 4.06 & 0.158 & Fail to Reject Ho & 0.06 & 0.56 \\
\hline-8 & 67 & 17.79 & 0.754 & Fail to Reject Ho & 0.27 & 0.83 \\
\hline-7 & 67 & 11.56 & 0.471 & Fail to Reject Ho & 0.17 & 1.00 \\
\hline-6 & 67 & -50.90 & -1.806 & Reject Ho & -0.76 & 0.24 \\
\hline-5 & 67 & 11.58 & 0.393 & Fail to Reject Ho & 0.17 & 0.41 \\
\hline-3 & 67 & -17.29 & -0.594 & Fail to Reject Ho & -0.26 & 0.15 \\
\hline-3 & 67 & 16.41 & 0.640 & Fail to Reject Ho & 0.24 & 0.39 \\
\hline-2 & 67 & -36.63 & -1.411 & Fail to Reject Ho & -0.55 & -0.16 \\
\hline-1 & 67 & -13.19 & -0.533 & Fail to Reject Ho & -0.20 & -0.36 \\
\hline 0 & 67 & 1.39 & -0.049 & Fail to Reject Ho & -0.02 & -0.38 \\
\hline 1 & 67 & 4.07 & 0.101 & Fail to Reject Ho & 0.06 & -0.32 \\
\hline 2 & 67 & 46.41 & 1.898 & Reject Ho & 0.69 & 0.37 \\
\hline 3 & 67 & 28.79 & 1.138 & Fail to Reject Ho & 0.43 & 0.80 \\
\hline 4 & 67 & -31.60 & -0.928 & Fail to Reject Ho & -0.47 & 0.33 \\
\hline 5 & 67 & 32.82 & 0.958 & Fail to Reject Ho & 0.49 & 0.82 \\
\hline 6 & 67 & 40.89 & 1.691 & Reject Ho & 0.61 & 1.43 \\
\hline 7 & 67 & 20.98 & 0.812 & Fail to Reject Ho & 0.31 & 1.74 \\
\hline 8 & 67 & -8.14 & -0.258 & Fail to Reject Ho & -0.12 & 1.62 \\
\hline 9 & 67 & -32.82 & -1.076 & Fail to Reject Ho & -0.49 & 1.13 \\
\hline 10 & 67 & -73.17 & -2.409 & Reject Ho & -1.09 & 0.04 \\
\hline 11 & 67 & -57.71 & -2.093 & Reject Ho & -0.86 & -0.82 \\
\hline 12 & 67 & 10.40 & 0.402 & Fail to Reject Ho & 0.16 & -0.66 \\
\hline 13 & 67 & -64.55 & -1.988 & Reject Ho & -0.96 & -1.62 \\
\hline 14 & 67 & 73.20 & 2.580 & Reject Ho & 1.09 & -0.53 \\
\hline 15 & 67 & 31.56 & 1.263 & Fail to Reject Ho & 0.47 & -0.06 \\
\hline 16 & 67 & 4.19 & 0.168 & Fail to Reject Ho & 0.06 & 0.00 \\
\hline 17 & 67 & 4.29 & 0.173 & Fail to Reject Ho & 0.06 & 0.06 \\
\hline 18 & 67 & -33.92 & -1.042 & Fail to Reject Ho & -0.51 & -0.45 \\
\hline 19 & 67 & 28.52 & 1.129 & Fail to Reject Ho & 0.43 & -0.02 \\
\hline 20 & 67 & -33.94 & -1.040 & Fail to Reject Ho & -0.51 & -0.53 \\
\hline
\end{tabular}

Table 1. Daily Average Abnormal Returns \& T Statistic as per Market Model

Significance at 0.05 percent 
and one day after $\left(\mathrm{t}_{1}\right)$ there is a positive Average Abnormal Return. This implies that there is a positive impact on the stock prices around the dividend announcements.

Table 2 has looked into Average Abnormal Return and $\mathrm{t}$ statistic in different event windows. It is observed from Table 3 that the Average Abnormal Return is highest in the window $\left(t_{0}-t_{3}\right)$. In the event window of $\left(t_{-}-t_{3}\right)$, there is a positive Average Abnormal Return but is not significant at 0.05 level of significance. This could be probably because of leakage of news or expectations of the market from the companies, which would have caused this increase in price. When considering the Average Abnormal Return across the entire event window $t_{-20}$ to $\mathrm{t}_{+20}$, a net sight Average Abnormal Return is seen, which is not significant and the null hypothesis cannot be rejected. This implies that there is a positive impact on the stock prices around the dividend announcement.

\section{CONCLUSION}

The study reveals that there exists a positive market reaction in case of dividend announcements. The study as mentioned earlier is done for a sample of 67 companies who announced dividends during April 2007 and August 2011. The findings of the study are consistent with the studies of Gordon (1962); Foster and Vickery (1978). There is an evidence of positive abnormal returns around the dividend announcement date, i.e., especially on the An date and 3 days post announcement. The share prices after that rapidly get adjusted to the information signifying Semi-Strong Form of Market Efficiency. The result holds true for select sample of companies and during the period considered for the study. There could probably be other factors, which might have an impact on the share price movement, which is not considered and which could be a limitation. In conclusion, it can be stated that dividend announcements do have an impact on the shareholders,

Table 2. Average Value of AAR across different Event Windows

\begin{tabular}{lrrl}
\hline $\begin{array}{l}\text { Event } \\
\text { Window }\end{array}$ & $\begin{array}{l}\text { AAR } \\
\%\end{array}$ & $\begin{array}{l}\text { T } \\
\text { Statistic }\end{array}$ & $\begin{array}{l}\text { Null Hypothesis } \\
\text { Test }\end{array}$ \\
\hline $\mathrm{t}_{-20}$ to $\mathrm{t}_{-3}$ & 2.27 & 0.26 & Fail to Reject $\mathrm{Ho}_{0}$ \\
$\mathrm{t}_{0}$ to $\mathrm{t}_{3}$ & 30.10 & 1.88 & Reject Ho \\
$\mathrm{t}_{-3} \mathrm{t}_{0} \mathrm{t}_{0}$ & -11.95 & -0.71 & Fail to Reject Ho \\
$\mathrm{t}_{-3}$ to $\mathrm{t}_{3}$ & 10.07 & 0.65 & Fail to Reject Ho \\
$\mathrm{t}_{3}$ to $\mathrm{t}_{20}$ & -4.49 & -0.34 & Fail to Reject Ho \\
\hline
\end{tabular}

Significance at 0.05 percent generating a positive market reaction in terms of the stock price and greater in terms of market capitalization.

\section{REFERENCES}

Ackerloff, G. (1970). The market for lemons: quality uncertainty and the market mechanism. Quarterly Journal of Economics, 84(4), 488-500.

Akbar, M., \& Baig, H. H. (2010). Reaction of stock prices to dividend Announcements and Market Efficiency in Pakistan. Lahore Journal of Economics, 15(1), 103-125.

Ball, R., \& Kothari, S. P. (1991). Security Returns around Dividend Announcements. The Accounting Review, 66(4), 718-738.

Bhattacharya, S. (1979). Imperfect Information, Dividend Policy, and 'The Bird in the Hand' Fallacy. The Bell Journal of Economics, 10(1), 259-270.

Balachandran, B. (1998). Dividend Reduction and Interim Effect: UK Evidence. www.ssrn.com with I.D. 114990

Black, F. (1976). The dividend puzzle. Journal of Portfolio Management, 2(2), 5-8.

Brown, S. J., \& Warner, J. B. (1985). Using daily stock returns: The case of event studies. Journal of Financial Economics, 14(1), 3-31.

Easterbrook, F. (1984). Two agency-cost explanations of dividends, American Economic Review, 74(4), 650-9.

Easton, A., \& Sinclair, A. (1989). The Impact of Unexpected Earnings and Dividends on Abnormal Returns to Equity. Accounting \& Finance, 29(1), 1-19.

Foster III W., \& Vickrey, D. (1978). The Information Content of Dividend Announcements. The Accounting Review, 53(2), 360-370.

Gordon, M. J. (1959). Dividends, earnings and stock prices. Review of Economics and Statistics, 41(2), 99-105.

Gordon, M. (1962). The Savings Investment and Valuation of a Corporation, the Review of Economics and Statistics, 44(1), 37-51.

Lonie, A. A., Abeyratna, G., Power, D. M., \& Sinclair, C. D. (1996) .The Stock Market Reaction to Dividend Announcements: A UK Study of Complex Market Signals, Journal of Economic Studies, 23(1), 32-52.

Lintner, J. (1956). Distribution of income of corporations among dividends, retained earnings and taxes, American Economic Review, 46(2), 97-113.

Michaely, R., Thaler, R. H., \& Woack, K. L. (1995). Price Reaction to dividend initiations and omissions over reaction or drift? Journal of Finance, 50(2), 573-608.

Miller,M., \& Rock, K. (1985). Dividend Policy underAsymmetric Information, Journal of Finance, 40(4), 1031-1051. 
Miller, H., \& Modigliani, F. (1961). Dividend Policy, Growth and the Valuation of Shares, the Journal of Business, 34(4), 411-433.

John, K., \& Williams, J. (1985). Dividends, Dilution and Taxes: A Signaling Equilibrium, Journal of Finance, 40(4), 1053-1070.

Pettit, R. (1972. Dividend Announcements, Security Performance, and Capital Market Efficiency, the Journal of Finance, 27(5), 993-1007.

Sharma, R. (2011). Stock Price Behavior around Dividend Announcements: An Event Study Methodology, Vilakshan, XIMB Journal of Management.

Spence, M. (1973). Job market signaling. Quarterly Journal of Economics, 87(3), 355-374.

\section{About the Author}

Dr. Kavita has a Masters degree in Business Administration and a $\mathrm{PhD}$ from Andhra University. She has over thirteen years of teaching experience in different B-Schools at India and West Indies. She has publications in many peer reviewed journals like South Asian Journal of Management, AIMS International Journal of Management, Asia Pacific Business Review to name a few. She also has many publications in National and International Conferences to her credit. Her areas of interest are Investment Banking, Banking, IPO Pricing. Currently she is Associate Professor in the area of Finance at Alliance Business School, Bangalore. She can be reached at kavita.chavali@, alliance.edu.in.

Ms Nusrathunnisa is Teaching Assistant in the area of Finance at Alliance University. Her areas of expertise are Accounting and Corporate Finance. Her current area of research focuses on two streams of research i.e. empirical studies in the area of Corporate Finance and Financial Markets, secondly on developing case studies in the related field of Finance. She is also actively participated in conducting and organizing seminars, workshops and industrial visits for management students. 